Jurnal Ilmu Administrasi Publik 7 (1) (2019): 1-11

DOI: http://dx.doi.org/10.31289/publika.v7i1.1992

Jurnal Administrasi Publik

http://ojs.uma.ac.id/index.php/publikauma

\title{
Akuntabilitas Pengelolaan Alokasi Dana Desa Di Desa Pitu Dan Lina Ino Kecamatan Tobelo Tengah Kabupaten Halmahera Utara
}

\author{
Richard Djiko*, Bagus Subardi* \\ *Program Studi Manajemen Bisnis, Politeknik Perdamaian Halmahera, Indonesia \\ **Program Studi Manajemen Bisnis, Politeknik Perdamaian Halmahera, Indonesia
}

Diterima Februari 2019; Disetujui April 2019; Dipublikasikan Juni 2019

\begin{abstract}
Abstrak
Penelitian ini bertujuan untuk mengetahui Besaran dana desa yang diterima di Desa Pitu dan Lina Ino pada Tahun 2016 dan 2017, besaran anggaran untuk belanja langsung (Pemberdayaan masayarakat desa), Besaran anggaran untuk Kegiatan Pembangunan Desa dan Akuntabilitas Pemerintah Desa Dalam Pemanfaatan Dana Desa. Jenis penelitian ini adalah penelitian kualitatif dengan pendekatan analisis deskriptif. Dari hasil penelitian dapat dijelaskan bahwa besaran dana desa yang didapat oleh desa Pitu pada tahun 2016 berjumlah Rp. 592.919.000, dan untuk tahun 2017 dana desa yang di dapat berjumlah Rp. 778,234,000. Untuk desa Lina Ino sendiri pada tahun 2016 mendapat dana desa Rp. 611,069,000 dan pada tahun 2017 Rp. 755,145,000. Desa Pitu dan Lina Ino di setiap tahunnya memanfaatkan anggaran ini untuk kegiatan pembangunan dan pemberdayaan masyarakat di buat guna menjawab apa yang menjadi permasalahan di masyarakat. Akuntabilitas pemerintah dalam mempertanggunjawabkan penggunaan dana desa di pertanggunjawabkan yakni pada Semester I paling lambat minggu ke empat bulan Juli tahun anggaran berjalan, Semester II paling lambat minggu ke empat bulan Januari tahun anggaran berikutnya, dan disertai dengan bukti-bukti pengeluaran yang sah. Yang menjadi permasalahan adalah masih kurangnya pertanggunjawaban pemerintah desa terhadap masyarakat, karena bentuk pertanggunjawaban yang di buat kepada masyarakat masih sangat sederhana.
\end{abstract}

Kata kunci : Akuntabilitas, Pemberdayaan Masyarakat, Pembangunan, Desa Pitu, Lina Ino.

\begin{abstract}
This study aims to determine the amount of village funds received in Pitu and lina Ino villages in 2016 and 2017, the amount of the budget for direct expenditure (Village community empowerment), and the amount of the budget for village Development activities and accountability of village governments in utilizing village funds. This type of research qualitative research with a descriptive analysis approach. From the results of the study it can be explained that the amount of village funds obtained by pitu village in 2016 amounted to Rp. 592,919,000, and for 2017 village funds can be amounted to Rp. 778,234,000. For the village of Lina Ino itself in 2016 received village funds of $R p .611,069,000$ and in 2017 Rp. 755,145,000. Pitu and Lina Ino villages each year utilize the budget for development activities and community empowerment created to solve what a problem in the community is. Government accountability in answering the use of Village funds accounted for namely in semester 1 or at the latest the fourth week of July of the current budget year. Semester II no is later than the fourth week of January of the following fiscal year, and accompanied by valid expenditure evidence. The problem is that there is still a lack of accountability of the village government to the community, because the from accountability made to the community is still very simple.
\end{abstract}

Keywords : Accountability, community empowerment, development, Pitu and Lina Ino Village

How to Cite : Djiko R, Subardi B. (2019). Akuntabilitas Pengelolaan Alokasi Dana Desa Di Desa Pitu Dan Lina Ino Kecamatan Tobelo Tengah Kabupaten Halmahera Utara, 7 (1) : 1-11

*Corresponding author:

P-ISSN-2549-9165

e-ISSN -2580-2011 


\section{PENDAHULUAN}

Desa merupakan perpanjangan tangan pemerintah dalam memberikan pelayanan kepada masyarakat. Kebijakan pemerintah dalam rangka pemerataan pembangunan adalah dengan memberikan Alokasi Dana Desa dan Dana Desa kepada desa agar dapat mandiri dalam mengurusi rumah tangganya sendiri. Pemberian kewenangan terhadap desa ini agar desa dapat mandiri dan terjadi pemerataan pembangunan. Akan tetapi dalam memberikan kewenangan desa pun harus bertanggungjawab terhadap pemerintah dan masyarakat terhadap apa yang di buat.

Untuk menjawab apa yang telah di percayakan oleh pemerintah melalui pemberian dana desa yakni dengan tujuan untuk melakukan perubahan dan pemerataan. Pembangunan diartikan oleh (riyadi dan deddy supriyadi bratakusumah, 2005). (Garis, 2017) bahwa pembangunan merupakan proses untuk melakukan perubahan.

Selain pembangunan tujuan pemeberian dana desa adalah bagaimana memberdayakan masyarakat desa. Tujuan Pemberdayaan masyarakat menurut Sumaryadi (2005, h.25) (Karimah, Saleh, \& Wanusmawatie, 2014) pada dasarnya yaitu untuk membantu pengembangan manusiawi yang otentik dan integral dari masyarakat yang lemah, miskin, marjinal dan kaum kecil serta untuk memberdayakan kelompok masyarakat tersebut secara sosio ekonomis sehingga mereka dapat lebih mandiri dan dapat memenuhi kebutuhan dasar hidup mereka namun sanggup berperan serta dalam pengembangan masyarakat.

Pada era demokrasi, di mana masyarakat selalu menuntut pemerintahan yang bersih, bertanggungjawab, dan transparan, kebutuhan terhadap akuntabilitas keuangan pemerintah semakin tinggi (Hupe \& Hill, 2007, Brusca \& Montesinos, 2006, Koppell, 2005). (Setyoko, 2011). Tuntutan ini diarahkan pada semua tingkatan pemerintahan, mulai dari pemerintah pusat hingga pemerintah desa.

Akuntabilitas dalam pemerintah desa sebagaimana yang diungkapkan oleh Sukasmanto (Astuty \& Fanida, 2013) melibatkan kemampuan pemerintah desa untuk mempertanggung jawabkan kegiatan yang dilaksanakan dalam kaitannya dengan masalah pembangunan dan pemerintahan desa. Pertanggung jawaban yang dimaksud menyangkut 
masalah finansial yang terdapat dalam APBDes dengan alokasi dana desa sebagai salah satu komponen didalamnya. Fungsi akuntabilitas lebih luas bukan hanya sekedar ketaatan kepada peraturan perundangan yang belaku. Akan tetapi, fungsi akuntabilitas tetap memperhatikan penggunaan sumber daya secara bijaksana, efisien, efektif dan ekonomis. Penyelenggaraan pemerintahan maupun penyelenggaraan perusahaan harus menekankan tujuan utama dari akuntabilitas, agar setiap pengelola atau manajemen dapat meyampaikan akuntabilitas keuangan dengan membuat laporan keuangan. Sedangkan tujuan dari kegiatan pemberdayaan masayarakat menurut menurut Sumaryadi (2005)(Karimah et al., 2014) pada dasarnya yaitu untuk membantu pengmbangan manusiawi yang otentik dan integral dari masyarakat yang lemah miskin, marjinal dan kaum kecil serta untuk memberdayakan kelompok masyarakat tersebut secara sosio ekonomis sehingga mereka dapat lebih mandiri dan dapat memenuhi kebutuhan dasar hidup mereka namun sanggup berperan serta dalam pengembangan masyarakat.
Di dalam penelitian ini mengkaji besaran dana desa yang diterima masingmasing desa, presentasi pos-pos anggaran yang digunakan untuk belanja langsung (Pemberdayaan masayarakat desa), dan penggunaan dana desa (DD) untuk program Pembangunan, (untuk mengetahui besaran presentasi pos-pos anggaran yang digunakan untuk pembangunan), dan bagaimana pertanggungjawaban pemerintah desa tentang bagaimana penggunaan anggaran untuk kegiatan pembangunan, pemberdayaan masyarakat desa dan penguatan kapasitas Pemerintah desa.

\section{METODE PENELITIAN}

Jenis penelitian ini adalah penelitian kualitatif dengan pendekatan analisis deskriptif. Usman dan Purnomo (2009) (Romantis \& Kurrohman, 2015) mengatakan bahwa penelitian deskriptif kualitatif adalah menguraikan pendapat responden apa adanya sesuai dengan pertanyaan penelitian, kemudian dianalisis dengan kata-kata yang melatarbelakangi Informan berperilaku seperti itu.

Lokasi penelitian di dalam penelitian ini adalah di Desa Pitu dan Lina Ino Kecamatan Tobelo Tengah Kabupaten 
Halmahera Utara. Data yang digunakan dalam penelitian ini adalah data primer dan data sekunder. Analisis data yang di pakai dalam penelitian ini menggunakan model dari Miles dan Huberman, (Rahmi Fajri, Endah Setyowati, 2015) Data Condensasion, Data Display, Drawing/Verifying Conclusion.

\section{HASIL DAN PEMBAHASAN}

Besaran dana desa yang diterima di Desa Pitu dan Lina Ino pada Tahun 2016 dan 2017

Berdasarkan Pasal 95 PP No. 43 Tahun 2014 tentang Peraturan Pelaksanaan Undang-Undang No.6 Tahun 2014 tentang Desa ditegaskan, Pemerintah mengalokasikan dana desa dalam APBN setiap tahun anggaran yang diperuntukkan bagi desa yang ditransfer melalui APBD Kabupaten/Kota. (Sugiantar, Wiasta, P.Perbawa, Wiryawan, \& Wijaya, 2016)

Dana desa merupakan bentuk perhatian pemerintah pusat kepada desa untuk pemerataan pembangunan. Sebagaimana yang dituangkan dalam (Peraturan Pemerintah Republik Indonesia Nomor 43 Tahun 2014 Tentang Peraturan Pelaksanaan Undang-Undang Nomor 6 Tahun 2014 Tentang Desa, 2014) pasal 1 Ayat 8 menjelaskan bahwa Dana Desa adalah dana yang bersumber dari anggaran pendapatan dan belanja negara yang diperuntukkan bagi Desa yang ditransfer melalui anggaran pendapatan dan belanja daerah kabupaten/kota dan digunakan untuk membiayai penyelenggaraan pemerintahan, pelaksanaan pembangunan, pembinaan kemasyarakatan, dan pemberdayaan masyarakat. Untuk mekanisme penyaluran, penggunaan, pemantauan dan evaluasi dana desa diatur dalam (Peraturan Menteri Keuangan Republik Indonesia Nomor 49/PMK.07/2016 Tentang Tata Cara Pengalokasian, Penyaluran, Penggunaan Pemantauan Dan Evaluasi Dana Desa) Pasal 1 ayat 2 menjelasakan bahwa Dana desa adalah dana yang bersumber dari anggaran pendapatan dan belanja Negara yang diperuntukan bagi desa yang ditransfer melalui Anggaran Pendapatan dan Belanja Daerah Kabupaten/kota dan digunakan untuk membiayai penyelenggaraan pemerintahan, pelaksanaan pembangunan, pembinaan kemasyarakatan, dan pemberdayaan masyarakat.

Untuk pembagian dana desa di setiap desa di seluruh Indonesia di bagi 
sesuai dengan ketentuan perundangundangan. Seperti yang termuat dalam peraturan menteri keuangan republik Indonesia Nomor 49/PMK.07/2016 tentang tata cara pengalokasian, penyaluran, penggunaan pemantauan dan evaluasi dana desa penghitungan rincian dana desa setiap desa dimuat dalam pasal 8 yakni besaran alokasi formula setiap desa dihitung dengan bobot sebagai berikut: (a). $25 \%$ (dua puluh lima persen untuk jumlah penduduk), (b). $35 \%$ (tiga puluh lima persen untuk angka kemiskinan), (c) $10 \%$ (sepuluh persen) untuk luas wilayah; dan (d). 30\% (tiga puluh persen), untuk tingkat kesulitan geografis. Untuk Tahun 2017 berubah jumlah jumlah besaran alokasi formula sesuai dengan ( Peraturan Menteri Keuangan Republik Indonesia Nomor 199/Pmk.07/2017 Tentang Tata Cara Pengalokasian Dana Desa Setiap Desa Kabupaten/Kota Dan Penghitungan Rincian Dana Desa Setiap Desa) Pasal 11 ayat 1 menjelaskan bahwa besaran alokasi formula setiap desa sebagaimana diatur dimaksud dalam pasal 8 ayat 2 huruf $\mathrm{c}$ dihitung dengan bobot sebagai berikut: (a). 10\% (sepuluh persen) untuk jumlah penduduk, (b) 50\% (lima puluh persen) untuk angka kemiskinan, (c). 15\% (lima belas persen) untuk luas wilayah dan (d). 25\% (dua puluh lima persen) untuk tingkat kesulitan geografis.

Dari ke dua regulasi yang di tetapkan diatas maka pada tahun 2016 dan 2017 besaran dana desa yang di dapat di desa Pitu adalah sebagai berikut sesuai dengan data sekunder yang di dapat di lokasi penelitian.

Tabel 1. Dana Desa Pitu Tahun 2016 dan 2017

\begin{tabular}{|l|l|c|}
\hline Tahun & Desa & $\begin{array}{c}\text { Besaran DD } \\
\text { (Rp) }\end{array}$ \\
\hline 2016 & Pitu & 592.919 .000 \\
\hline 2017 & Pitu & $778,234,000$ \\
\hline
\end{tabular}

Sumber : Data Pendapatan Dana Desa Tahun 2016 \& 2017 Desa Pitu (diolah)

Untuk desa lina Ino sendiri besaran dana desa yang di dapat pada tahun 2016 dan 2017 sebagai berikut berdasarkan data sekunder yang di dapat di lokasi penelitian:

Tabel 2. Dana Desa Lina Ino Tahun 2016 dan 2017

\begin{tabular}{|l|l|l|}
\hline Tahun & \multicolumn{1}{|c|}{ Desa } & $\begin{array}{c}\text { Besaran DD } \\
(\mathrm{Rp})\end{array}$ \\
\hline 2016 & Lina Ino & $611,069,000$ \\
\hline 2017 & Lina Ino & $755,145,000$ \\
\hline
\end{tabular}

Sumber : Data Pendapatan Dana Desa Lina Ino Tahun 2016 \& 2017 (diolah) 
Berdasarkan data sekunder diatas Desa Pitu dan lina di tahun 2016 dan 2017 mendapatkan dana desa, akan tetapi berdasarkan hasil wawancara. Tidak serta merta dengan adanya dana desa apa yang menjadi permasalahan di masyarakat dapat diselesaikan, akan tetapi masih saja ada program yang telah di buat belum dapat di realisasi, karena dana desa yang diberikan belum mencukupi.

Menurut (Sugiantar et al., 2016) Tujuan alokasi dana desa tersebut secara umum adalah: (a) Menanggulangi kemiskinan dan mengurangi kesenjangan; (b) Meningkatkan perencanaan dan penganggaran pembangunan di tingkat desa dan pemberdayaan masyarakat; (c) Meningkatkan

pembangunan infrastruktur perdesaan; Meningkatkan pengamalan nilai-nilai keagamaan, sosial budaya dalam rangka mewujudkan peningkatan sosial; (e) Meningkatkan ketentraman dan ketertiban masyarakat; (f.) Meningkatkan pelayanan pada masyarakat desa dalam rangka pengembangan kegiatan sosial dan ekonomi masyarakat; (g) Mendorong peningkatan keswadayaan dan gotong royong masyarakat; (h) Meningkatkan pendapatan desa dan masyarakat desa melalui Badan Usaha Milik Desa (BUMDesa).

Melalui dana desa tujuan pemerintah sudah sangat jelas seperti apa yang di kemukakan oleh Sugiantar, yakni menjawab apa yang menjadi permasalahan di masyarakat, yakni, pengentasan kemiskinan, pelaksanaan pembangunan, peningkatan pelayanan kepada masyarakat, dan peningkatan keswadayaan kepada masyarakat, gotong royong serta meningkatan pendapatan desa serta masyarakat desa.

\section{Besaran Anggaran Untuk Belanja} Langsung (Pemberdayaan masayarakat desa)

Pada tahun 2016 Desa Pitu mendapatkan dana desa yang di peruntukan untuk kegiatan pemberdayaan masayarakat desa berjumlah $\mathrm{Rp}$ 248,020,700, dan untuk tahun 2017 sendiri Rp. 234,325,000. Untuk desa Lina Ino sendiri pada Tahun 2016 mendapatkan dana Desa untuk kegiatan pemberdayaan masyarakat berjumlah $\operatorname{Rp} 143,977,000$, dan pada tahun 2017 dana desa yang di dapat untuk kegiatan pemberdayaan masyarakat berjumlah Rp 226,100,000. Berdasarkan hasil wawancara dengan kepala desa, sekretaris desa, bendahara desa dan ketua 
BPD desa lina Ino dan desa Pitu menjelaskan bahwa pembagian dana desa untuk kegiatan pemberdayaan telah di sepakati bersama dari awal kegiatan musrenbangdes menurut mereka bahwa memang tidak semua hal yang disepakati dan direncanakan dapat terjawab dalam penganggaran tiap tahun berjalan. Hal tersebut dikarenakan mengingat bahwa adanya keterbatasan dana sehingga ada program yang telah di sepakati namun belum dapat terrealisasi pada tahun tersebut. Pada akhirnya, programprogram tersebut tertunda untuk tahunanggaran berikutnya.

\section{Besaran anggaran untuk Kegiatan Pembangunan Desa}

Desa Pitu dan Lina Ino pada tahun 2016 dan 2017 mendapatkan dana untuk kegiatan pembangunan Desa. Berdasarkan data sekunder yang di dapat di desa Pitu Pada Tahun 2016 Dana desa yang diperuntukan untuk kegiatan pembangunan berjumlah Rp. 344,898,300. Untuk Tahun 2017 sendiri dana desa yang diperuntukan untuk kegiatan pembangunan berjumlah Rp.539,100,000. Menurut Pengakuan kepala desa Pitu jumlah dana desa Pitu yang diperuntukan untuk kegiatan pembangunan meningkat.
Di dalam peraturan Bupati nomor 6 tahun 2017 tentang Tata Cara Pembagian Dan Penetapan Rincian Dana Desa Setiap Desa Dalam Kabupaten Halmahera Utara Pasal 6 ayat 2 menjelaskan bahwa Dana desa digunakan untuk membiayai penyelenggaraan pemerintahan, pembangunan dan pemberdayaan masyarakat dan diayat 3 menjelaskan bahwa penggunaan dana Desa mengacu pada RPJMdes dan RKPDes. Amanat Peraturan buapati diatas sangat jelas bahwa pemanfaatan dana Desa diperuntukan untuk kegiatan Pembangunan di desa.

Pembangunan diartikan oleh (riyadi dan deddy supriyadi bratakusumah, 2005). (Garis, 2017) bahwa pembangunan merupakan proses untuk melakukan perubahan. Hal ini menjelaskan bahwa pembangunan merupakan suatu proses untuk melakukan perubahan. Dengan adanya Otonomi Desa sehingga desa diberikan kepercayaan untuk mengelola dana desa untuk kegiatan pembangunan. Pemberian dana desa untuk kegiatan pembangunan dengan tujuan agar terjadi pemerataan pembangunan dari Kota ke Desa. 
Akuntabilitas Pemerintah Desa Dalam Pemanfaatan Dana Desa

Desa Pitu dan desa Lina Ino merupakan salah satu desa yang berada di kecamatan Tobelo Tengah Kabupaten Halmahera Utara. Kedua desa tersebut pada tahun 2016 dan 2017 mendapatkan dana desa. Dalam mempertanggungjawabkan pemanfaatan dana desa pemerintah desa berperan penting untuk hal ini. Menerapkan prinsip akuntabilitas merupakan suatu hal yang sangat penting, dimana hal-hal yang berkaitan dengan keuangan merupakan suatu hal yang sangat sensitif bagi setiap orang.

Berdasarkan hasil wawancara dengan kepala desa lina Ino dan Pitu beserta perangkat desa menurut mereka bahwa bentuk pertanggungjawaban pemanfaatan dana desa talah di atur dalam peraturan Bupati Halamahera Utara nomor 6 Tahun 2017 tentang tata cara pembagian dan penetapan rincian dana desa setiap desa dalam daerah Kabupaten Halmahera Utara, pasal 9 Ayat 1 menjelaskan Kepala desa menyampaikan laporan keuangan penggunaan dana desa kepada bupati, C.q Kepala Badan Keuangan dan aset daerah Kabupaten Halmahera Utara setelah diteliti dan diperiksa oleh tim Verivikasi Kabupaten dan disampaikan kepada kepala badan pemberdayaan Masyarakat dan pemerintahan desa dan Inspektorat. Sedangkan dalam Pasal 2 menjelaskan bahwa penyampaian realisasi penggunaan dana desa di lakukan dengan ketentuan: (a). Semester I paling lambat minggu ke empat bulan Juli tahun anggaran berjalan. (b). Semester II paling lambat minggu ke empat bulan Januari tahun anggaran berikutnya. Dari regulasi diatas maka dapat dijelaskan bahwa bentuk pertanggunjawaban pemerintah desa di laporkan untuk semester pertama paling lambat minggu ke empat bulan Juli pada tahun anggaran berjalan, dan untuk pelaporan pada semester berikutnya pada bulan Januari tahun anggaran berikutnya.

Berdasarkan hasil wawancara dengan informan menjelaskan bahwa laporan pertanggunjawaban pemanfaatan dana desa harus disertai dengan buktibukti pemanfaatan anggaran yang sah sehingga kredibilatas laporan tersebut dapat di pertanggungjawabkan. Permasalahan yang terjadi saat ini adalah bagaimana mempertanggungjawabkan apa yang telah di buat kepada masyarakat. Menurut pengakuan masyarakat sampai saat ini pertanggungjawaban pemerintah 
terhadap masyarakat masih sangat sederhana yang di buat oleh pemerintah yakni melalui papan pengumuman yang ditaruh di kantor desa dan dibuatkan baliho tentang berapa besar dana yang di dapat untuk masing-masing kegiatan pemanfaatan anggaran.

Menurut mereka hal ini masih sangat disayangkan karena informasi yang di dapat oleh masyarakat masih sangat kurang. Begitu juga dengan aparat yang ada di desa, menurut mereka di dua tahun terakhir yaitu pada tahun 2016 dan 2017 bentuk pertanggunjawaban pemerintah desa kepada masyarakat masih sangat kurang, hal ini disebabkan karena masih kurangnya sosialisasi terhadap masyarakat tentang pemanfaatan dana desa.

Akuntabilitas dalam pemerintahan desa sebagaimana yang diungkapkan oleh Sukasmanto (Astuty \& Fanida, 2013) melibatkan kemampuan pemerintah desa untuk mempertanggung jawabkan kegiatan yang dilaksanakan dalam kaitannya dengan masalah pembangunan dan pemerintahan desa. Pertanggung jawaban yang dimaksud menyangkut masalah finansial yang terdapat dalam APBDes dengan alokasi dana desa sebagai salah satu komponen didalamnya. Fungsi akuntabilitas lebih luas bukan hanya sekedar ketaatan kepada peraturan perundangan yang belaku. Akan tetapi, fungsi akuntabilitas tetapi memperhatikan penggunaan sumber daya secara bijaksana, efisien, efektif dan ekonomis.

Penyelenggaraan pemerintahan maupun penyelenggaraan perusahaan harus menekankan tujuan utama dari akuntabilitas, agar setiap pengelola atau manajemen dapat meyampaikan akuntabilitas keuangan dengan membuat laporan keuangan.

\section{KESIMPULAN}

Dari hasil penelitian dapat dijelaskan bahwa besaran dana desa yang didapat oleh desa Pitu pada tahun 2016 berjumlah Rp. 592.919.000, dan untuk tahun 2017 dana desa yang di dapat berjumlah Rp. 778,234,000. Untuk desa Lina Ino sendiri pada tahun 2016 mendapat dana desa Rp. 611,069,000 dan pada tahun 2017 Rp. 755,145,000. Desa Pitu dan Lina Ino di setiap tahunnya memanfaatkan anggaran ini untuk kegiatan pembangunan dan pemberdayaan masyarakat dengan adanya dana desa yaitu untuk menjawab apa yang menjadi permasalahan di masyarakat. Batas waktu pemerintah 
pelaporan penggunaan dana desa di pertanggunjawabkan yakni pada Semester I paling lambat minggu ke empat bulan Juli tahun anggaran berjalan, Semester II paling lambat minggu ke empat bulan Januari tahun anggaran berikutnya, dan disertai dengan bukti-bukti pengeluaran yang sah.

Namun demikian, yang menjadi permasalahan adalah masih kurangnya pertanggungjawaban pemerintah desa terhadap masyarakat, karena bentuk pertanggunjawaban yang di buat kepada masyarakat masih sangat sederhana.

\section{UCAPAN TERIMAKASIH}

Terimahkasih kepada Kemenristekdikti yang telah memberikan kepercayaan kepada penulis, sehingga telah diberikan kesempatan untuk mengambil bagian dalam penelitian dosen pemula.

\section{DAFTAR PUSTAKA}

Astuty, E., \& Fanida, E. H. (2013). Akuntabilitas Pemerintah Desa Dalam Pengelolaan Anggaran Pendapatan Dan Belanja Desa (Apbdes) (Studi Pada Alokasi Dana Desa Tahun Anggaran 2011 Di Desa Sareng Kecamatan Geger Kabupaten Madiun). Jurnal Online Program Studi S-1 Ilmu Administrasi Negara Fakultas IImu Sosial UNESA, 1(2). Retrieved from http://jurnalmahasiswa.unesa.ac.id/i ndex.php/publika/article/view/2533 /5599

Garis, R. R. (2017). Analisis Implementasi 4 Program Prioritas Kementerian Desa Pembangunan Daerah Tertinggal Dan Transmigrasi Di Kabupaten Ciamis (Studi kasus pada lima desa di kabupaten Ciamis). Moderat: Jurnal Ilmu Pemerintahan, 3(2), 108-130. Retrieved from https://jurnal.unigal.ac.id/index.php /moderat/article/view/689

Karimah, F., Saleh, C., \& Wanusmawatie, I. (2014). Dalam Pemberdayaan Masyarakat (Studi pada Desa Deket Kulon Kecamatan Deket Kabupaten Lamongan). Jurnal Administrasi Publik (JAP), 2(4), 597-602. Retrieved fromhttp://administrasipublik.stude ntjournal.ub.ac.id/index.php/jap/arti cle/view/428/312

Peraturan Menteri Keuangan Republik Indonesia Nomor 199/Pmk.07/2017 Tentang Tata Cara Pengalokasian Dana Desa Setiap Desa Kabupaten/Kota Dan Penghitungan Rincian Dana Desa Setiap Desa. Indonesia. Retrieved from http://www.djpk.kemenkeu.go.id/wp -content/uploads/2018/01/PMK199-Tahun-2017.pdf

Peraturan Menteri Keuangan Republik Indonesia Nomor 49/PMK.07/2016 tentang tata cara pengalokasian, penyaluran, penggunaan pemantauan dan evaluasi dana desa. Retrieved (http://www.jdih.kemenkeu.go.id/ful lText/2016/49 PMK.07 2016Per.p df)

Peraturan Pemerintah Republik Indonesia Nomor 43 Tahun 2014 Tentang 
Peraturan Pelaksanaan UndangUndang Nomor 6 Tahun 2014 Tentang Desa (2014). Indonesia. Retrieved (https://peraturan.bkpm.go.id/.../PP 472015 Perubahan PP 43 2)

Rahmi Fajri, Endah Setyowati, S. (2015). Akuntabilitas Pemerintah Desa Pada Pengelolaan Alokasi Dana Desa (ADD) (Studi pada Kantor Desa Ketindan , Kecamatan Lawang , Kabupaten Malang). Jurnal Administrasi Publik (JAP), 3(7), 1099-1104. Retrieved from http://administrasipublik.studentjou rnal.ub.ac.id/index.php/jap/article/vi ew/920/389

Romantis, P. A., \& Kurrohman, T. (2015). Akuntabilitas Pengelolaan Alokasi Dana Desa Di Kecamatan Panarukan Kabupaten Situbondo Tahun 2014 ( Management Accountability of Alokasi Dana Desa At Panarukan District Situbondo Regency Year 2014). Retrieved from repository.unej.ac.id

Setyoko, P. I. (2011). Akuntabilitas Administrasi Keuangan Program Alokasi Dana Desa ( ADD ). JIANA (Jurnal Ilmu Administrasi Negara), 11(1), 14-24. Retrieved from ejournal.unri.ac.id

Sugiantar, A. A. P. W., Wiasta, I. W., P.Perbawa, K. S. L., Wiryawan, I. W. G., \& Wijaya, I. M. H. (2016). Pertanggungjawaban Alokasi Dana Desa Pelaga Terkait Program Pemberian Alokasi Dana Desa Kabupaten Badung. Jurnal Advokasi FH Unhas, 6(1), 109-121. Retrieved (http://jurnal.unmas.ac.id/index.php /advokasi/issue/view/58)
Peraturan Bupati Nomor 6 Tahun 2017 Tentang Tata Cara Pembagian Dan Penetapan Rincian Dana Desa Setiap Desa Dalam Kabupaten Halmahera Utara

Data Pendapatan Dana Desa Lina Ino Tahun 2016 \& 2017. (Unpiblished)

Data Pendapatan Dana Desa Tahun 2016 \& 2017 Desa Pitu (Unpiblished) 